\title{
Slum Upgrading: The Muungano Wa Wanavijiji
} Vision

\section{Ezekiel Rema}

\section{(2) OpenEdition}

1 Journals

\section{Electronic version}

URL: https://journals.openedition.org/eastafrica/526

DOI: 10.4000/eastafrica.526

ISSN: 2790-1076

\section{Publisher}

IFRA - Institut Français de Recherche en Afrique

\section{Printed version}

Date of publication: 1 September 2011

Number of pages: 55-63

ISSN: 2071-7245

\section{Electronic reference}

Ezekiel Rema, "Slum Upgrading: The Muungano Wa Wanavijiji Vision", Les Cahiers d'Afrique de l'Est / The East African Review [Online], 44 | 2011, Online since 07 May 2019, connection on 09 December 2021. URL: http://journals.openedition.org/eastafrica/526 ; DOl: https://doi.org/10.4000/eastafrica. 526

This text was automatically generated on 9 December 2021.

Les Cahiers d'Afrique de l'Est / The East African Review 


\title{
Slum Upgrading: The Muungano Wa Wanavijiji Vision
}

\author{
Ezekiel Rema
}

\section{Slum Upgrading according to Muungano Wa Wanavijiji (MWW)}

1 Slum upgrading means improving the life of people in the informal settlements through provision of water, infrastructure, socio-economic activities, decent structures among other facilities. The term "slum upgrading" refers to the access to basic rights and security of tenure for communities in need, which have survived for many years without adequate housing and basic rights. This is the definition that was agreed upon in the international conventions on human rights in the United Nations (UN) guidelines.

However, for Muungano and the slum upgrading victims, this term means eviction. Past experiences, witnessed by those in areas where these projects have taken place, have seen communities left homeless, landless and with no property and means of livelihood because the projects have always involved corruption. Consequently, communities are always against slum upgrading whenever the Government proposes it. For example, the Kibera slum upgrading has not picked up from the time it was launched seven years ago. Furthermore, this Government initiative on slum upgrading has never worked well because there is no slum upgrading policy to guide implementing bodies.

3 In order to probe the issues and implications surrounding slum upgrading, the following interview with Mr. Rema sought to establish Muungano's strategies in this process, their achievements and the challenges they face in the course of promoting civic awareness on land rights and decent housing for slum residents. Muungano's contribution to the wider Kenyan reforms on slum upgrading is also highlighted in reference to key national issues of the recently promulgated Constitution and related land and housing policies. 


\title{
Interview with Mr. Rema, Chairman of Muungano
}

\begin{abstract}
I) WHAT ARE THE STRATEgIES THAT MUUNgANO USES TO SENSITIZE THE CIVIL SOCIETY, THE GOVERNMENT AND THE PUBLIC IN UNDERSTANDINg WHAT IS NEEDED TO SECURE AND TO PROTECT LAND RIgHTS OF PEOPLE LIVING IN SLUM COMMUNITIES?
\end{abstract}

Muungano has employed various strategies in its sensitization campaigns with regard to land rights. First, we gave our proposals during the National Land Policy formulation process, which focused mainly on the regularization of the informal settlements. The policy recognizes that land is not for private ownership but recommends accessibility of land to each Kenyan. This policy calls on the National Land Commission to make land accessible to all land users without any discrimination.

From 2002, Muungano started involving the Government in its activities so as to share Government policies with the community and the Ministries of Land, Housing and Local Government. In this way, Muungano was able to gain considerable influence to obtain land, for free, from the Government. We also created land banks for the poor to access land in the city, where it is very expensive. Muungano also managed to advocate for housing incentives which were incorporated in the policy that guides the community on how to access money through housing cooperative societies.

Currently, Muungano is participating in the development of the Land Use policy, the Urban Development Planning Policy and finalizing the Eviction and Resettlement Guideline. Muungano has been and still continues to lobby the Government to put appropriate measures for the long-term resolution of the slum problem.

II) DO YOU WORK WITH OTHER NON-GOVERNMENTAL ORgANISATIONS (NGOS) WHICH SUPPORT THE FORMULATION AND IMPLEMENTATION OF SLUM UPGRADING POLICIES? HOW MANY OTHER NGOS IN NAIROBI OR IN KENYA SHARE SIMILAR gOALS TO MUUNGANO'S?

Yes we work together with other NGOs in the formulation and implementation of slum upgrading namely Pamoja Trust, Shelter Forum, Haki Jamii, Amnesty International, Kituo Cha Sheria, Cohre, Umande Trust, Kenya Land Alliance and the Kenya Human Rights Commission (KHRC).

Muungano is a member of the Civil Society on Land and Housing Coalition where we participate in meetings, forums, seminars and workshops to deliberate on issues affecting our communities and to find ways of dealing with these issues as a coalition. For instance, we are actively involved in the development of policies so as to contribute to the debate on these reforms while offering effective and well-informed policy and legal options to the slum upgrading process.

III) WHO ARE YOUR MAIN DONORS IN SLUM UPGRADINg PROJECTS?

Muungano is a social movement that advocates for development and security of tenure in slums. The saving schemes are a key donor for the federation through daily savings for housing projects. Moreover, Akiba Mashinani Trust (AMT) acts as the financial wing of the federation through fund-raising from international donors who give loans for our housing projects. 
iv) What ARe your views ON THE New CONSTItUtion, PARTICULARLy Chapter 4, ARTICLE 41(1)? DID MUUNgANo PARTICIPATE IN THE DEVELOPMENT OF THIS NEW LEgAL FRAMEWORK?

Chapter Four of the new Constitution contains the Bill of Rights and Article 41(1) talks about each person in Kenya having the right to fair labour practices. Muungano participated in giving views in various forums and forwarded proposals to the commissions. We were all interested in seeing the recognition of our informal businesses, residential and other rights. As Article 41(1) recognizes this fair treatment by the authorities, it also serves our interests.

v) ACCORDINg TO YOU, IS THERE A STRONg RELATIONSHIP BETWEEN LAND gOVERNANCE AND SLUM UPGRADING? IF YES, KINDLY EXPLAIN.

Yes, there is a relationship between land governance and slum upgrading. The community must get assurance from the land offices that the land proposed for development is the same land where this development shall be. We have seen houses worth millions pulled down because of poorly planned projects and lack of understanding between developers and the land offices.

VI) TO WHAT EXTENT ARE THE LAND POLICIES IN KENYA TAKING INTO ACCOUNT THE SLUM ISSUES?

The house/land policy is giving the guideline on how the government should solve the problems/issues of slums. The Land Policy (p.50) provides for strategies dealing with slum issues.

VII) TO WHAT EXTENT IS MUUNGANO INVOLVED IN THE NATIONAL LAND POLICY? WHAT DO YOU THINK OF CHAPTER 3.4.1.5 OF THIS NATIONAL LAND POLICY?

From 2004, when the process of developing the National Land Policy was initiated to the time it was passed in 2008, Muungano has been involved in this process with other social movements such as the Kenya Land Alliance and Haki Jamii. We mobilized the public in all regions regarding these national land policy documents. We held two rallies in Kisumu and in Mombasa and when we were on our way to Rift Valley, at Nakuru, the Parliament passed the National Land Policy the same day.

Very specifically, Chapter 3.4.1.5 of the National Land Policy addresses the informal sector and the ways in which the Government should plan for informal sector activities in both urban and rural areas. Due to the gravity of lack of employment in the country, the Government should support the country's economy in an active way. The policy states that the government should plan for and support the access of space and people carrying out their activities without any harassment from the State or private developers. As pointed out earlier, Chapter Four of the Bill of Rights of the new constitution clearly states in Article 40(1) that individuals/groups can own property in any part of Kenya without any kind of discrimination.

Guiding principles on land allocation for settlement and previous allocation are also given in the policy's Chapter 3.5.3. Usually, no considerations are made for the poor when land allocation is done therefore, Chapter 3.6.9 is crucial as it outlines issues of informal settlements. Overall, this land policy states the measures the Government will take to solve the problem of informal settlements country-wide namely: taking an inventory, as a first step in knowing how many informal settlements exist and on which land and establishing whether it is public or private suitable for human habitation in order to plan settlements. 
The Government is also expected to put measures in place to prevent the growth of slums. This necessitates a good community participatory system and consultative process to avoid conflict.

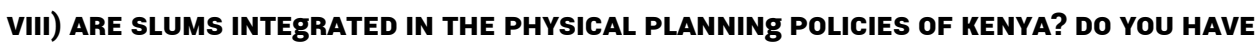
SOME PARTICULAR STRATEgIES ON HOW THE RAPID GROWTH OF SLUMS IN KENYAN CITIES AND TOWNS CAN BE MANAgEd AS A RESULt OF URBAN POVERTY, HIgH COSTS OF LIVINg, OBSCURE LAND ALLOCATION-SYSTEMS AND INSUFFICIENT INVESTMENT(S) IN NEW LOWINCOME HOUSINg?

Previously, physical planning in Kenya never considered the interests of slums but the National Land Policy (Article 3, 6.9, p. 50) states that the Government shall set programmes to address the issues of informal settlements and the state of their working condition. In this context, measures to be taken into consideration are:

- The government should first understand the state of informal settlements by conducting an inventory exercise in all slums country-wide;

- The creation of awareness, to squatters, of those lands which are not suitable for human habitation;

- Identification of land for relocations after consultations with the beneficiaries;

- Dispute resolution committees;

- Provision of basic services to those who are occupying public land while planning for upgrading with the community.

Muungano has strategies in managing the rapid growth of slums in Kenya as it operates in municipal towns and other upcoming urban centers. Nationally, we organize the communities around issues of basic rights e.g. land and housing while initiating negotiations with local authorities for land allocations. In order to gain financial independence, we encourage communities to form saving groups where they can use their daily/weekly savings for small businesses and housing. We also organize for exchange visits to those settlements that have managed to do housing projects. This is aimed at helping our people to learn and to have confidence in the federation approach to resolving issues of unemployment and lack of low-cost housing.

IX) ACCORDINg TO YOU, WHICH IS THE BEST WAY TO IMPROVE THE ENVIRONMENTAL CONDITIONS IN THE SLUMS? DO YOU HAVE SOME EXAMPLES OF THIS?

The issue of environment in the slum upgrading discourse is very critical. My view is that the government, through the Ministry of Environment, should first identity spaces within the slums that can be used as garbage collection centers instead of allowing dumping on the roadside. Ablution blocks should be built along the rivers to discourage those people who drain pit latrines into rivers and communities should also be encouraged to care for their surroundings. For instance, tree planting can be done through bi-monthly public meetings in the villages. In this way, people will understand the importance of the environment and they will begin to protect it like in Kibera. On Karanja road in Kibera, the youth there are manning the road and preventing the haphazard dumping of waste. Previously, residents used to dump waste along the road which eventually resulted in conflicts among the residents. These are some of the environmental aspects that need to be urgently taken into consideration so as to upgrade slums in an environmentally-conscious way. 


\section{X) AFTER 10 YEARS OF MUUNGANO'S OPERATIONS, DO YOU THINK THAT YOU HAVE EXERTED SOME INFLUENCE IN SLUM UPGRADING POLICY FORMULATION AND REFORMS?}

Yes. Muungano has greatly influenced the development of the slum upgrading policy even though it has not yet been realized. The Government uses the slum upgrading guideline to carry out slum upgrading projects. As it is not a legal framework, slum upgrading projects continue to fail. Due to public demand, the Government has accepted to start the process of developing the slum upgrading policy.

\section{XI) WHAT ARE MUUNGANO'S ACHIEVEMENTS WITH REgARD TO SLUM UPGRADING IN NAIROBI?}

In Nairobi city/county, Muungano's members are now occupying their own houses in five informal settlements i.e. Kambi Moto, Gitathuru, Mahira, Kahawa Soweto and Ghetto village. Other settlements, for example, Mashimoni, Mabatini and Marigu-ini are negotiating on this issue with the relevant authorities where we have slum upgrading in partnership with the Government through the Kenya Slum Upgrading Programme (KENSUP).

The slum upgrading programme has so far worked without much conflict between the structure owners and tenants which can be attributed to Muungano's efforts. The success of Muungano lies in its bottom-up approach which is in sharp contrast to the Government's top-down approach. We encourage participation through meetings with the stakeholders to discuss critical issues like land ownership, individual access to a house and house size (depending on the land size). The community is involved in land enumeration and it uses the enumeration reports to engage or negotiate with the local authorities on future developments whereby greater participation is ensured through allocation of different roles to various teams in the communities.

While negotiating with the relevant authorities, the community organizes mobilization activities targeting the whole community and it raises money through a daily savings system. In the same meeting where savings are submitted, members also come up with house designs in a process known as "house dreaming." Each member comes up with his/her house model and shares it. Eventually, one house model is chosen by all the members after taking into consideration the land size and the total population. After choosing one house model, an architect assists the members of the community in professionally designing the house model. This facilitates easy approval by the local authority planners.

During the house construction, the community forms a procurement committee and a working programme/timetable for members to provide unskilled labour. This helps them to reduce the cost of construction which is very expensive for the poor individual. Pamoja Trust, a not-for-profit organization that seeks to promote access to land, shelter and basic services for the urban poor, formed a financial wing known as Akiba Mashinani Trust (AMT) to give credit financing to those groups/schemes that have projects such as house construction, land buying and for small business loans to Muungano members only. In this regard, Muungano has expanded its activities to a national level and in all municipalities, by mobilizing communities to come together and start savings for housing through housing co-operative societies which have incentives from the Ministry of Co-operatives as guided by the Housing policy and bill. 
XII) ACCORDINg TO YOU, HAVE YOU SUCCEEDED IN FACILITATING STRATEgIC LINKAgES BETWEeN gROUPS AND STAKEHOLDERS AT DIFFERENT LEVELS IN SUPPORT OF SLUM UPGRADINg EFFORTS?

The federation has helped in creating linkages with other stakeholders like those in informal settlements. We have housing projects where the issue of structure owners has been solved because the majority of residents in slums are poor. We encourage them to contribute daily savings to raise funds and loan each other money for small businesses and eventually, for housing so as to improve their living conditions.

XIII) IN YOUR OPINION, WHAT IS THE MAIN DIfICULTY IN THE FORMULATION AND IMPLEMENTATION OF SLUM UPgRADING POLICIES IN KENYA? WHAT IS THE MAIN CHALLENgE?

The main difficulty in the formulation and implementation of slum upgrading policies is that the government has not yet mandated the Ministry of Housing to start the process of developing the slum upgrading policy. They have a guideline which was developed with public participation but when KENSUP tries to implement slum upgrades using it, they tend to experience difficulties. Among some of the main challenges we can mention are:

- The Government tends to address land ownership issues in isolation from the communities. It should do so together with the communities before initiating housing projects to avoid conflicts that hinder the process;

- Lack of funding to improve low-income housing: the Ministry of Finance should increase funds to the housing sector because it is a national disaster;

- Lack of civic awareness. There is a great need to sensitize the community on slum upgrading so that they support the projects;

- Weak partnerships with the private sector: since the private sector engages in house development and the Government finds it easier to let them handle this, it may consider housing as its priority in budget allocations.

Xiv) WHAT LESSONS AND RECOMMENDATIONS CAN MUUNGANO SHARE IN ORDER TO ACHIEVE A VERITABLE SLUM UPgRADINg?

\section{Lessons Learnt}

- Bottom-up approaches in slum upgrading increase the chances of a successful slum upgrading as communities participate in all the steps and house allocations are done in a fair, transparent and consultative manner;

- With government assistance, communities in informal settlements can raise money and access loans from micro-finance banks and conduct housing project without fear of eviction(s);

- Community participation and provision of labour by the slum resident enables them to gain skilled labour. This involvement has also reduced age, financial and gender discrimination in informal settlements where Muungano has done slum upgrading as everyone, including women, is equally and actively involved.

Projects are completed with this approach and the community's concerted efforts. The housing construction takes a short time to be completed because it is the beneficiary who builds it. They are motivated and they give their best in order to get a new home;

\section{Recommendations}


In order to minimize the housing demand in urban areas, the Government should:

- Develop the slum upgrading policy;

- Increase funds for housing and provide housing incentives through the annual national budget;

- Involve communities from inventory/enumerations, planning to the implementation of slum upgrading. When all stakeholders are well informed about the project, no conflicts will arise during the slum upgrading and the project shall be achieved. In addition to this, when issues of land ownership are solved, it is easier for the community to have confidence in their investment(s);

- Invite other development partners to support slum upgrading since it is a national programme, even those communities with rural needs have a right to benefit from slum upgrading;

- Identify land for those who are situated in vulnerable areas. Evictions should be stopped and measures be established on how to re-settle squatters occupying private land, riparian, road, railway and power line reserves;

- Provide appropriate technology that will facilitate low-cost material which the common citizen can afford;

- Review building codes and develop slum-friendly codes;

- Coordinate housing development country-wide for both Civil Society Organisations (CSOs) and the Government;

- Regularize all informal settlements to give communities residing on the land confidence in housing development;

- Provide training for skilled labour for the informal settlements;

- Facilitate exchange programmes for an improved learning process, both locally and internationally, where best practices on slum upgrading are found.

\section{ABSTRACTS}

This article explores the concept of slum upgrading as understood by Muungano wa Wanavijiji (MWW), a federation of slum dwellers in Nairobi (hereafter referred to as Muungano). It discusses different issues related to slum upgrading projects in Nairobi in two ways: through a description of what slum upgrading means to Muungano and through an interview with Ezekiel Rema, Chairman of Muungano and one of the eighteen founding members of this federation in 1996, who shares the various aspects of Muungano's activities and experiences in the slum upgrading process. In conclusion, the article presents some lessons and recommendations, as suggested by Mr. Rema, on how to achieve a veritable slum upgrading.

\section{INDEX}

\section{Geographical index: Kenya}


AUTHOR

\section{EZEKIEL REMA}

Founding member and Chairman of Muungano wa Wanavijiji (MWW), federation of slum Dwellers since 1998, Nairobi, Kenya. 